\title{
Muhalefetin Siyasal Alanda İnşası: Rus Muhalif Lider Aleksey Navalnıy’ın Konuşmalarının Retorik Analizi*
}

\section{Construction of the Opposition in the Political Sphere: Rhetorical Analysis of Russian Opposition Leader Alexei Navalny's Political Speeches}

\author{
Dr. Öğr. Üyesi Erkam TEMIR (D)1, Prof. Dr. Bünyamin AYHAN(D2
}

\begin{abstract}
$\ddot{\mathbf{O} z}$
Siyasal iletişim, insanlık tarihinde siyaset, devlet ve iktidar yapısı ile birlikte irdelenen en eski alanlardan biri olarak ortaya çıkmaktadır. Özellikle toplum, grup ve bireyin kendini ifade etme ve kamuoyu oluşturma sürecinde etkili olan siyasal iletişimin, günümüz medya araçları ile demokratik toplumların vazgeçilmezi haline geldiğini söylemek mümkündür. Siyasal iletişim araçları ve siyasal iletişim için kullanılan metotlar aynı zamanda toplumsal yapıların özelliklerini de göstermektedir. Sovyet Sosyalist Cumhuriyetler Birliği yıkılışına kadar kendine has bir iletişim sistemi uygulamıştır. Sovyet Sosyalist Cumhuriyetler Birliği’nin dağılmasından sonra ise hibrit post-sovyet siyasal sistem organize olmuştur. Bu yeni sistem ise kendi iktidar ve siyasal araçlarını üretmiştir. Bu süreçte genel olarak demokratik teamüller yerleşememiş̧ir. Muhalefet ve muhaliflik gibi kavramlar baskı ve sansürle birlikte anılır hale gelmiştir.
\end{abstract}

Gelişen iletişim teknolojileri ile birlikte muhalifler kendi alanlarını açmaya çalışmaktadır. Bunlardan biri de muhalif lider Aleksey Anatolyeviç Navalnıy'dır. İktidarın geleneksel medyaya ulaşmasını engellemesi nedeniyle siyasal iletişim faaliyetlerini yoğun olarak sosyal medyaya taşımıştır. Navalnıy, kullandığı siyasal iletişim teknikleri ile toplumun geniş bir bölümünün dikkatini çekmiş ve hızla ciddi bir destekçi kitlesi oluşturmuştur. Kullandığı ikna odaklı siyasal iletişim stratejileri ve retorik de bunda etkili olmuştur. Çalışmada Aleksey Navalnıy'ın siyasi konuşmaları retorik analizi ile incelenmiştir.

Anahtar Kelimeler: Rusya, Aleksey Navalnıy, muhalefet, retorik analizi, siyasal iletişim

Makale Türü: Araştırma

\begin{abstract}
Political communication is one of the oldest areas in the history of mankind, along with politics, state and power structure. Political communication is especially effective in the process of self-expression of society, group and individuals and in the process of creating public opinion. Now it is becoming an indispensable element of democratic societies with the media tools of today. The means of political communication and the methods used also show the characteristics of social structures. Until the fall of the USSR, it has implemented a unique communication system. After the disintegration of the Soviets, the hybrid postSoviet political system was organized and produced its own power and political means. In this process, democratic conventions could not be settled, and the opposition was remembered with oppression and censorship.
\end{abstract}

Along with the developing communication technologies, opposition try to open their own fields. One of them is opposition leader Alexei Navalny. Because the power has prevented him from reaching the traditional media, he intensified his political communication activities on social media. Navalny has drawn public attention with the political communication techniques he used and quickly formed a serious

\footnotetext{
* Bu çalışma, Erciyes Üniversitesi Sosyal Bilimler Enstitüsünde Erkam Temir tarafından sunulmuş olan doktora tezinden üretilmiştir.

${ }^{1}$ Kastamonu Üniversitesi, İletişim Fakültesi, erkamtemir@gmail.com.

${ }^{2}$ Selçuk Üniversitesi, İletişim Fakültesi, bayhan@ @elcuk.edu.tr.

Atıf için (to cite): Temir, E. ve Ayhan, B. (2020). Muhalefetin siyasal alanda inşası: Rus muhalif lider Aleksey Navalnıy'ın konuşmalarının retorik analizi. Afyon Kocatepe Üniversitesi Sosyal Bilimler Dergisi, 22(2), 575-592.
} 
supporter mass. Persuasion-oriented communication strategies and rhetoricthat he used have been effective in this. In this study, Navalny's political speeches were examined with rhetorical analysis.

Keywords: Russia, Alexei Navalny, opposition, rhetoric analysis, political communication

Paper Type: Research

\section{Giriş}

Günümüzde Ritzer'in hesaplanabilirlik ilkesini kullanan ve "McDonaldslaşma" olgusu doğrultusunda hareket eden siyasiler çeşitli araştırmalarla davranışlarının ve söylemlerinin hedef kitleleri üzerinde oluşturduğu etkiyi ölçtürmektedirler. Davranışlarını ve söylemlerini bu araştırmaların sonuçlarına göre etkiyi arttıracak şekilde kurgulamaktadırlar. Bu durumda ortaya konulan söylem ve davranışlarda samimi olmanın, onlara inanıp inanmamanın önemi azalmakta, bu söylem ve davranışların toplumda nasıl bir izlenim oluşturacağına odaklanılmaktadır (Mulgan, 1995, s. 39).

Siyasal iletişimde anlatma başat öneme sahiptir. Retorik ise anlatma eylemi de dahil olmak üzere içeriği anlamlı kılan tüm unsurlarla ilgilenmektedir. İletişim alanında retorik çalışmaların taşıdığı önemi bilhassa son dönemde yapılan çalışmaları gözlemleyerek görmek mümkündür. Nitekim bugün çeşitli saygın üniversiteler retorik dersleri vermekle yetinmeyip özellikle iletişim bilimlerini kapsayacak şekilde bünyelerinde müstakil birer bölüm olarak "retorik bölümleri" açmaktadırlar. Ayrıca siyasilerin kullandıkları retorikleri analiz eden akademik çalışmaların sayısı da giderek artmaktadır.

Bu nedenle retorik, siyasetin ve siyasal iletişimin hem en eski hem de en güncel meselesi olarak ortaya çıkmaktadır. Retorik hem metnin üretilmesi ile hem de incelenmesi ve analizi ile ilgilenmektedir. Başlıca ilgi alanları sözün kudretini ortaya çıkartmak, konuşmayı önceden planlayarak amaçlanan hedeflere ulaşmak, konuşmacı, dinleyici ve anlatılan konu arasındaki etkileşimi irdelemek, hakikat ve dil arasındaki ilişkiyi araştırmak, hatibin ahlaki yükümlülüklerini ortaya koymak ve "öncesi ve sonrasıyla konuşma sürecini eğitim-öğretimin konusu haline getirebilmektir." Retorik en üstte ikna aracının bulunduğu bir piramittir. Bu piramidin basamakları aşağı doğru giderek farklılaşmakta ve ayrıntılar artmaktadır (Tepebaşı11, 2016, s. 716). Kelimelerin doğasında tam bir matematiksel kesinlik olmadığ için (Lieber, 1880, s. 25-41) ampirik bir retorik analizi, teorik bir yorum ile iç içe düşünülmelidir. Nitekim anlama eyleminin söz konusu olduğu her yerde yorumdan da söz etmek gerekir.

$\mathrm{Bu}$ makalede, Post-Sovyet dönemde siyasi ve sosyal alanlarında marjinal değişiklikler yaşamış Rusya'da, kendine has siyasal iletişim tarzı ve retoriği ile kitleleri peşinden sürüklemeyi başaran muhalif lider Aleksey Navalnıy'ın kullandığı retorik analize tabi tutulmuştur.

\section{Post-Sovyet Rus Siyaseti ve Siyasal İletişim Sistemi}

1991 yılında Rusya'da yeni anayasa reddedilerek kurucu seçimler iptal edilmiştir. SSCB'nin mirası olan çeşitli kurumsal düzenlemeler kısmi olarak korunmuştur. 1993 yılına gelindiğinde Cumhurbaşkanı Boris Yeltsin ve parlamento arasında keskin bir anlaşmazlık ortaya çıkmıştır. "Sıfır toplamlı oyun" ile çözülen anlaşmazlık yeni anayasanın kabul edilmesine katkı sağlamıştır. 1996 yılında Yeltsin bir dizi kötü muamelenin eşlik ettiği adaletsiz bir kampanya sonrasında tartışmalı bir şekilde yeniden seçilmiş ancak meclisin tasfiye edilmesi ve muhalefet partilerinin kapatılması önerilerini reddetmiştir. 1999-2000 yıllarında Yeltsin'in yerine getirdiği Putin rakiplerine galip gelerek cumhurbaşkanlığı seçimlerini kazanmıştır (POLİT NNOV, 2018). Uyguladığı "uzlaşılmış konsensüs" mekanizması ile politik, ekonomik ve toplumsal aktörlerin sadakatini zorlayarak iktidarını en üst düzeye çıkarmıştır. 2003-2005 yılları arasında Putin ve onun kontrolünde hareket eden tekelci egemen grubun karşısındaki gerçek ve muhtemel engeller

\footnotetext{
${ }^{3}$ Bir tarafın kazancının diğerinin kaybına eşdeğer olduğu durum. Bakınz: Neumann, J. V. and Morgenstern, O. (1953). Theory of Games and Economic Behavior, Princeton: Princeton University Press.
} 
ortadan kaldırılarak siyasi tekeli garanti altına alacak şekilde seçim yasalarında değişiklikler yapılmıştır. 2007-2008 yıllarına gelindiğinde iki dönem cumhurbaşkanlığı yapan Putin yasa gereği tekrar cumhurbaşkanlığına aday olamayınca yerine "sadık bir halef olan" Dmitri Medvedev'i seçtirmiş ve kendisi başbakanlık görevini üstlenmiştir. Hemen akabinde Medvedev cumhurbaşkanının yetkilerinin genişletilmesine ilişkin anayasa değişikliklerini yürürlüğe koymuştur. 2011-2012 yıllarında Putin kimilerince şaibeli görülen bir seçimin ardından Medvedev ile "iş takası" yaparak tekrar cumhurbaşkanı seçilirken Medvedev ise başbakanlık görevini üstlenmiştir. Seçimlerin şaibeli olduğu iddiasıyla ülkede büyük protestolar düzenlenmiştir. Bu protestolar "pro-demokratik" bir siyasi muhalefetin ortaya çıkmasına ve değişimlere yönelik kitlesel taleplerin artmasına katkı sağlamıştır. 2014 yılında Ukrayna'daki istikrarsız ortamdan faydalanan Rus hükümeti ülkenin güneydoğu bölgelerinde kanlı bir çatışmaya girerek Kırım'ı ilhak etmiştir (PRAVO, 2014). Böylelikle "varoluşsal düşmanı" olan batının Avrasya'da yükselişine müsaade etmeyeceği mesajını vermiştir. Ayrıca bu ilhakı iç politikada bir militarizasyon ve baskı aracı olarak kullanmıştır (Gel'man, 2015, s. 13-14).

Kriz siyasi olgularla birlikte diğer alanlara da sıçramış ve Aralık 2014'te ABD doları karşısında değer kaybetmeye başlayan Rus Rublesi birkaç ay içerisinde değerinin yarısından fazlasını kaybetmiş̧tir (CBR, 2019). 2015 yılının şubat ayında Putin'e ağır eleştirilerde bulunan, hatta hakaret eden (RUSSIAHOUSENEWS, 2016) eski başbakan yardımcısı muhalif aktivist Boris Nemtsov Moskova'da vurularak öldürülmüştür. Cinayetin arkasında Putin'in iradesi olduğu iddia edilmiştir (SVOBODA, 2017a). 2015 Kasım ayında Rus Su-24 uçağı Türk savaş uçağı tarafından düşürülmüştür. Ocak 2016'da İngiltere'de yapılan soruşturmada eski Rus istihbarat subay1 ve Kremlin eleştirmeni Aleksander Litvinenko'nun öldürülmesine ilişkin emrin muhtemelen Putin tarafından verildiği kararı duyuruldu (NYTIMES, 2016). 2017-2018 y1lları arasında St. Petersburg metrosunda gerçekleşen bombalı terör saldırısında 13 kişi hayatını kaybetti. Rusya 2016 ABD başkanlık seçimlerine müdahale etmekle suçlandı. Eski casusu Sergey Skripal ve kızının İngiltere'de yine Rusya tarafından zehirlendiği iddia edildi. 2018 seçimlerinde Putin yeniden başkan seçildi (BBC, 2018).

2011-2012 seçimlerinden önce, çoğu uzman, Rus toplumunun ülkenin siyasi statüsüne karşı varoluşsal bir tehdit oluşturmadığ görüşündeydi (Gel'man, 2013, s. 6). 2011'den önce yaşanan oldukça zayıf, dağınık, belirli bölgelerle kısıtlı ve dar kapsamlı sokak protestoları (Evans, 2012; Koesel and Bunce, s. 2012) analistlerce mühim görülmemişti. Ancak seçimlerden sonra yaşanan yoğun sokak protestoları çoğu analist için adeta bir sürpriz niteliğindeydi (Volkov, 2012, s. 55). O günden bugüne giderek yükselen yeni muhalefet ve halk protestoları, Putin rejimi içindeki istikrarsızlığın kanıtı olarak değerlendirilmeye başlamıştır. Ancak bu görüşe karş1 çıkanlar da vardır (Chebankova, 2015, s. 244).

Rusya'ya ile ilgili yapılan analizlerde çoğu uzman Alfred Evans gibi düşünmektedir. Buna göre "Eğer Rusya demokrasiye geçiş yaptıysa, bu geçiş başarılı olmamıştır." (Evans, 2011, s. 40). Böylelikle Rusya otoriter bir rejim yapısına sahiptir ve sivil toplum ve siyasi muhalefet ancak rejimi meşrulaştırmak için bulunmaktadır ve gerçekte karşıt yetenekten mahrumdur. Putin rejiminin baskıcı önlemlerinin yanı sıra Rus makamları ayrıca kasıtlı bir biçimde kurgulanmış ve devlet tarafindan onay gören sözde çekişme biçimlerini kolaylaştıran mekanizmalara sahiptir. Bu çekişme biçimlerinin üstlendiği rol ise çoklarına göre kesinlikle tartışmaya açıktır (Cheskin and March, 2015, s. 261-267).

Sovyet sosyal yönetim modelini geride brrakarak Rusya'da yeni bir siyasi sisteminin ortaya çıkmasının karmaşık süreçleriyle bağlantılı olarak, sivil toplum ve kurumlar arasındaki etkileşimde de çelişkiler ortaya çıkmıştır. Rusya'nın piyasa ekonomisine geçişiyle birlikte, toplumda sosyo-ekonomik, sınıfsal ve durumsal farklılaşmalar meydana gelmiştir. "Siyasi çıarların ve onları ifade eden güçlerin heterojen bir kitlesi ortaya çıkmıştır ve sonuç olarak, politik yaşamdaki katılımcılar arasında bir fikir birliği yoktur." Bir konsensüs geleneği olmadığı belirtilmektedir. Siyasal iletişimin en önemli araçlarından biri siyasi partiler ve sosyo-politik kurumlardır. Ancak, Rusya'da siyasi partilerin toplumun çıkarlarını ifade etme yeteneklerinin de 
oldukça kısıtlı olduğu vurgulanmaktadır. Sivil toplumun çıkarlarının temsilinin sadece formel bir hal almış durumda olduğu belirtilmektedir. Siyasi partilerde temsil kabiliyetinin yok denecek kadar az olduğu ifade edilmektedir (Marozova, 2010, s. 312-317).

Siyasal iletişimin, bilgi zenginliğini ve bütünlüğünü sağlayarak siyasi aktörlerin meşruluğunu arttırması ve siyasi süreçlerin içeriğini ve mantığını toplumun çeşitli gruplarının oluşturduğu beklentiler ve çıkarlar açısından yansıtması beklenmektedir. Ancak bu bağlamın gerçekleşmesi kitle iletişim araçlarının genel ve ekonomik yapısı, tekelleşmiş durumda olması veya farklı siyasi gruplar tarafindan demokratik bir biçimde erişebiliyor olması, toplumda oluşan birbirinden farklı taleplerin siyasi alana ne derecede yansıdığ 1 gibi birçok faktöre bağlıdır. Böylelikle Rusya'da siyasal iletişimin işleyişini incelemek için toplumda egemen olan beklentilerin siyasi alana ne derecede yansıdığını ele almak gerekmektedir. Birçok araştırmacı, ekonomik ilişkiler sistemi ile başlayarak, Rus toplumunda sosyal ilişkilere dair tüm sistemlerin son derece zayıf kurumsallaşmış olduğuna dikkat çekmektedir. Buna göre Rusya'da siyasetin semantiği kendisinin ve meşruiyet ihtiyacı kapsamının ötesine geçememektedir. Böylelikle Rusya'da siyasal iletişim tüm türleri siyasilerin kendi sosyal beklentilerini topluma yaymaya çalışmanın ötesine geçememektedir (Alekseyev, 2010, s. 11-17).

\section{Retorik Kavramı}

Retorik (İngilizce: Rhetoric, Rusça: Риторика) fikirleri beğenilecek şekilde ifade etme işidir. Temelde ikna etmek gayesi taşımakla birlikte, siyasette yarar elde etmek için, mahkemede adalet sağlamak için vb. dili tesirli, dikkat çekici bir şekilde kullanma sanatı olarak ifade edilmektedir. Temelde Antik Yunanda Sofistler tarafından geliştirilmiştir. Bu gelişimin öncülerinden olan Gorgias "sözün en az çabayla tanrısal ürünlere ulaşan büyük bir güç" olduğunu belirtmiş̧tir (Cevizci, 1999, s. 731).

Retorik ustası Gorgias'ın kendini bir çeşit büyücü gibi gördüğü ve adeta tılsımlı sözcükler söylüyormuşçasına kafiyeli konuşmayı oldukça sevdiği söylenmektedir (Theodore, 2010, s. 43). İlerleyen dönemde İsokrates ve diğer bazı düşünürler tarih yazımının da retoriğin bir alanı olarak değerlendirilmesi gerektiği belirtmektedirler. Çünkü "Eski zamanlarda tarih yazıcılığı miti, efsaneyi, vatansever coşkuyu, ahlaki aydınlatmayı, siyasi gerekçelendirmeyi ve nadir bulunan üslupsal ustalık unsurunu içerirdi. Nadiren gerçeklerle ilgili bir mesele" olarak karşımıza çıkmaktadır (Eagleton, 2012, s. 119). Aristo iletişimi "ikna etmenin bütün uygun anlamları" olarak tanımlarken iknayı "birini bir konuda inandırma, bir şey yapmaya razı etme" olarak tanımlamaktadır (Yüksel vd., 1994, s. 4-29).

Meyer (2009, s. 7-9) retoriği eski ve yeni reotirik olarak ikiye ayrır. O eski retoriği "karışıklık bilimi”" olarak adlandırırken, yeni retoriği "çoklu yanıt bilimi” olarak tanımlamaktadır. Buna göre retorik geçmişten beri çokları için menfi bir mana ifade etmektedir ve muhtevası belli olmayan, şüpheli ve kesinleşmemiş bir kavramdır. Bu sebeple retorik adeta bir "karışıklık bilimi"dir. Retoriğin ortaya çıkış1 ise Sicilya'da despotluğun çöküşü ile olmuştur. Mülklerini kaybedenlerin bu mülkleri tekrar elde edebilmeleri için davalarını savunmaları gerekmiştir. Böylelikle Sofistler devreye girerek mağdurları savunmak gayesiyle "bilgelik dersleri" vermeye başlamıştırlar. Sofistler böylelikle kısa bir süre zarfında "kendileri satmayı" başarmışlardır. Bu sebeple retorik siklıkla Platon'un tenkitlerine maruz kalmıştır. Buna göre retorik gerçek olmayan veya yanıltıcı iddialara dayanmaktadır. Böylelikle Sofizmin yanlış akıl yürütme olarak algılanması ve görünürde öyle olmamasına rağmen aldatıcı olduğu kanısı yaygınlaşmıştır. Buna göre retorik doğru düşüncenin tam zıddı, sofist ise filozofun antitezidir. Platon'un sofistlere sert eleştirileri retoriğin de kaderini etkilemiştir. Bu olumsuz imaj nedeniyle retorik düşüncelerin manipülasyonu, aldatma, propaganda vb. gibi algılanmıştır.

Eagleton'a göre (2006, s. 68) kapitalist toplumlar retoriğe, abartmaya, egzotizm vb. giderek daha bağımlı bir hale gelmektedir. Adorno'ya göre (2014, s. 61-62) retorik "ifadenin düşünce için muhafazasını" sağlamaktadır ve "retorik felsefede dil dışında düşünülemeyecek olanı" temsil etmektedir. Retoriğin ikna etme amacı onu tekdüzeleştirmekte ve yozlaştırmaktadır 
ancak ikna amacı olmaksızın retorik edinim pratikten uzaklaşacaktır. Baudrillard (2012, s. 114) ise tıpkı bir bedenin organik veya mekanik bir saldırı neticesinde acı çekmesine benzer bir şekilde dilin de retorikten acı çektiğini, rahatsızlı duyduğunu ve formunu koruyamadığını söylemektedir. Bu sebeple kimi zaman dilin sağlığına kavuşması için eleştirel ve klinik bir inceleme gerekebilir.

Platon'un hayali kahramanı Phaedrus'un retoriğe yönelik saldırıları Derrida'nın “Platon'un Eczanesi”nde (Derrida, 1999, s. 63-81) boyut kazanmıştır. Derrida'ya göre klasik retoriğin kategorileri oldukça tartışmalıdır. Onun batı geleneğine karşı olan muhalifliği o kadar sert ve tavizsizdir ki retoriğin ustaları olarak adlandırılan sofistler bile onun saldırısından kurtulamamışlardır (Megill, 1998, s. 420).

"Retorik halka açık konuşma sanatının bilimidir" (Sternin, 2003, s. 5). Retoriğin söylemleri inceleme gayreti onun etkili bir isteme, ikna etme ve tartışma biçimi bulma çabasından kaynaklanmaktadır. Retorikçiler kendi söylemlerinde kullanılabilmek için başkalarının konuşmalarını inceleme gayreti içerisine girmiştir. $\mathrm{Bu}$ sebeple retorik hem etkili söylemin pratiğini hem de bilimini ifade etmektedir (Eagleton, 2014, s. 213).

\subsection{Retorik ve Siyasal İletişim}

Retorik de tıpkı siyaset gibi aşırı idealize edilmediği takdirde kendi başına olumsuz ya da dürüstlükten uzak bir mefhum değildir (Solomon, 2004, s. 37). Siyaset alanında retorik çalışmalar, siyasi fikirler ve karar alma konusundaki yaygın bakış açılarına bir alternatif olarak sunulabilir (Condor, 2013, s. 3). Gill ve Whedbee'nin de belirttiği gibi retoriğin temel faaliyet alanı siyaset arenasıdır (Van Dijk, 1997, s. 157). Siyasal iletişimde dil çalışmalarının disiplinler arası bir boyutu vardır. Siyaset dili çalışmaları siyasilerin ve hedef kitlelerinin (dinleyicilerin) sosyo-ekonomik durumları, psikolojileri, kültürel hayatları vb. gibi dilbilimle ilgili olmayan diğer birçok etkenle de ilgilidir. Siyaset dili göreceli olarak basittir çünkü hitap ettiği kesim eğitim seviyesi olarak birbirinden oldukça farklı olabilir. Ayrıca basit olmasının diğer bir nedeni genel itibari bir yazı dili değil konuşma dili olmasından kaynaklanmaktadır. Siyasal iletişimde kullanılan dilin evrensel manada analizi yapılırken yalnızca kelimeler, cümleler ya da metinlerle ilgilenmez. O içeriği anlamlı kılan tüm unsurlarla ilgilenmektedir (Boyer, 1996, s. 3-4).

Borradori, Habermas ve Derrida'nın etkisiyle retorik, iletişim, imaj, medya vd. bir "enformasyon makinesi"dir demektedir. Bu enformasyon makinesi ise hem siyasi hem teknik hem de ekonomiktir (Borradori, 2008, s. 116). Rowland'a göre retorik adeta politik sistemimizin kanıdır. Bu kan damarlarımızda düzgün bir şekilde dolaştı̆̆ takdirde yaptığımız tercihler doğrultusunda etkili kararlar alırız. Düzgün bir şekilde dolaşmadığında ise birçok aksaklık ve problemle baş başa kalırız. Retoriğin sosyal bilimlerin ilk çalışma alanlarından biri olmasının ve insanlık tarihi ile eșdeğer geçmișe sahiptir. İnsanların birtakım kararlar verdiği her toplumda sahip olunması gereken iki önemli yetenek bulunmaktadır. Bunlar: İkna edebilme ve başkasını dinleyerek bir değerlendirme yapabilme. Bu yüzden geçmişte "doğru" olan şey günümüz toplumunda "daha doğrudur." Çünkü günümüz toplumunda iletişim süreci hızlanmış ve iletişime katılım artmıştır. Bir siyasi kampanyada retorik adeta adayların yatırım yaptığı bir tür değerdir. $\mathrm{Bu}$ yatırım ile adaylar insanları kendileri için oy kullanmaya ikna etmek isterler (REVOLVY, 2017). Siyasal ikna ise "önceden belirlenmiş, amaçlı ve niyetli iletişim ve mesaj yöntemleriyle seçmen kitleleri üzerinde bir tercih ve davranış değişikliği” oluşturmaktır (Çobanoğlu, 2007, s. 157).

\subsection{Retorik Unsurlar}

Berger'in Aristo'dan aktardığına göre retoriğin üç ana çeşidi bulunmaktadır, bunlar: Müzakereci, hukuki ve methedici retoriktir (Berger, 2000, s. 54). Öte yandan Berger "Medya ve İletişim Araştırma Metotları" kitabında "Ortak Retorik Aygıtların Mini Sözlügüu” başlığı altında iletişim çalışmalarında retorik analizi için alegori, aliterasyon, anlam belirsizliği, antitez, karşılaştırma, tanımlama, övgü, örneklendirme, ironi, metafor, benzetme, metonimi, sinekdoka, 
kafiye ve ritim unsurlarından da faydalanmak gerektiğini belirtmektedir ve bu unsurları şöyle siralamaktadır (Berger, 2016, s. 90-96):

Alegori/Kinaye (Allegory): Aliterasyon/Tekrar/Ses yineleme (Alliteration): Anlam belirsizliği (Ambiguity): Antitez (Antithesis): Karşılaştırma (Comparison): Tanımlama (Defination): Övgü (Encomium): Örneklendirme İroni/Hiciv/Tersinleme (Irony): Metafor (Metaphor): Benzetme (Simile): Metonimi/ Düzdeğişmece / Ad aktarması / Mecâz-1 Mürsel (Metonymy): Sinekdoka (Synecdocha): Kafiye (Rhyme): Ritim (Rhythm): ${ }^{4}$

\subsection{Mantıksal Yanılgılar}

Mantıksal yanılgılar (Logical Fallacies) makul veya yüzeysel olarak doğru gibi görünen ancak aslında kusurlu veya hileli ifadelerdir. Bu ifadeler tespit edildiğinde okuyucu/dinleyici yazarın/konuşmacının bilgisiz veya aldatıcı olduğunu düşünmektedir. Yazar veya konuşmacının mantıksal yanılgıları bilerek kullandığı durumlar aldatıcı olarak değerlendirilebilir (CARSONNEWMAN UNIVERSITY, 2019).

Mantıksal yanılgıların, bunların birer yanılgı olmasından dolayı etkisiz birer strateji oldukları anlamına gelmemektedir. Mantıksal yanılgılara başvurmak yanıltıcı oldukları için ahlaki sayılmamakta ve mantıksal olarak doğru bulunmamakla birlikte bu onların kitleleri etkilemekte oldukça güçlü bir yöntem olarak kullanıldığı gerçeğini değiştirmemektedir.

Alev Alat1ı İngilizce "fallacy" kelimesini "safsata" olarak ifade etmiş ve bunların ilk bakışta muteber gibi görünmesine rağmen yakından bakıldığında aslında sahte argümanlar olduğunu belirtmiştir. Alatlı kinayeli bir şekilde siyasetçilerin bu safsataları öğrenerek sık sık kullanmalarının gelecekleri için iyi bir yatırım olacağını belirtirken, dinleyicilerin ise bu safsataları bilmelerinin kolay kandırılmamak için faydalı olacağını belirtmektedir (Alatlı, 2001, s. 20-21). Böylelikle mantıksal yanılgılar siyasi retorikte sıklıkla kullanılmaktadır.

Mantıksal Yanılgılar sahte fakat popüler inançlardır ve aldatıcı argümanlardır. Modern mantıksal yanılgılar araştırmaları formel (biçimsel) ve informel (serbest/biçimsel olmayan) mantıksal yanılgılar olarak ikiye ayrılmaktadır. Formel mantıksal yanılgılar öncüllerin inkâr edildiği mantıksal yanılgılardır. Tanımlanabilir, geçersiz mantıksal formları ifade etmektedir (STANFORD, 2015). Formel mantıksal yanılgılar bir argümanı teknik olarak geçersiz kılmaktadır. Bu tür mantıksal yanılgılarda sonuçlar öncülleri/önermeleri izlememektedir. Burada sorun varılan sonucun (çıkarsamanın) doğru veya yanlış olması değildir. Sorun çıkarsamanın doğru öncüllere dayanmıyor olmasındadır (Alatl1, 2001, s. 19).

Bo Bennett bir eserinde üç yüz farklı informel mantıksal yanılgıdan bahsetmektedir (Bennett, 2012). Alatlı ise yaygın olarak kullanılan informel mantıksal yanılgıyı on başlıkta (2001, s. 7-85) şöyle sıralamaktadır: Belirsizlik, hatalı kıyaslama, hatalı kategorilendirme, konunun özünden uzaklaştırma, saldırı, şaşırtma, tartışmalı sebep, istatistiksel hata, otoriteye başvurma ve duygulara başvurma. ${ }^{5}$

\section{Metodoloji}

\subsection{Araştırmanın Amacı ve Yöntemi}

Araştırmanın amacı Rus siyasi muhalif Aleksey Navalnıy'ın hedef kitlesini etkilemek için siyasal iletişim kapsamında kullandığı retoriğin analiz edilmesidir. Demokratik olmayan bir zeminde kullandığ siyasi retorik ve siyasal iletişim yöntemiyle görece etki oluşturmayı başarabilmiş olması, onun kullandığı retoriği siyasal iletişim açısından incelemeye değer kılmaktadır. Bu analiz neticesinde siyasi retorik için teorik olarak belirlenen birtakım kurallara

\footnotetext{
${ }^{4}$ Detaylı Bilgi İçin Bakınız: Temir, E. (2019). Siyasal İletişimde Retorik: Aleksey Navalnıy Örneği, Erciyes Üniversitesi Sosyal Bilimler Enstitüsü, Doktora Tezi, Kayseri, s. 96-100.

${ }^{5}$ Detaylı Bilgi İçin Bakınız: Temir, E. (2019). Siyasal İletişimde Retorik: Aleksey Navalnıy Örneği, Erciyes Üniversitesi Sosyal Bilimler Enstitüsü, Doktora Tezi, Kayseri, s. 100-111.
} 
uyulup uyulmadığı, mevcut retorik yöntemlerin uygulanıp uygulanmadığı irdelenmeye çalışılacaktır.

Araştırma soruları:

- Aleksey Navalnıy'ın görece başarısına etki eden retorik unsurlar nelerdir?

- Aleksey Navalnıy’ın kullandığı retoriğin ikna bileşenleri nelerdir?

- Aleksey Navalnıy'ın kullandığı retoriğin diğer rakiplerinden farklı yönleri nelerdir?

- Aleksey Navalnıy'ın kullandı̆̆ı retoriğin genel argümanı nedir?

Konuşmalardan metne dökülen Rusça içerik Türkçeye tercüme edilmiştir. Sonrasında ilgili konuşmalar literatürde belirtildiği şekliyle retorik analizine tabi tutulmuştur.

\subsection{Evren ve Örneklem}

Çalışmanın evrenini Aleksey Navalnıy'ın yaptığı konuşmalar oluşturmaktadır. Çalışma kapsamında Navalnıy tarafından yapılmış beş farklı konuşma analiz edilmiștir. Bu konuşmalar Navalnıy'ın resmi youtube kanalı üzerinden yayınladığı Rusça konuşmalardan seçilmiştir. Örneklem oluşturulurken 2013-2017 yılları arasında her yılın en çok görüntülenen (resmi youtube kanalı verilerine göre) konuşması seçilmiştir.

Tablo 3. 2013-2017 yılları arasında her yılın en çok görüntülenen konuşması

\begin{tabular}{lrrr}
\hline Konuşmanın Başlı̆̆ı & Süre & $\begin{array}{r}\text { Görüntülenme } \\
\text { Sayıs1 }\end{array}$ & $\begin{array}{r}\text { Yayın } \\
\text { Yı1ı }\end{array}$ \\
\hline O Dimon Değil & $49: 39$ & 27.486 .936 & 2017 \\
Vladimir Putin Damadına 1,75 Milyar doları Nasıl & $4: 26$ & 1.156 .978 & 2016 \\
Aktardı? & $4: 13$ & 603.151 & 2015 \\
Aleksey Navalnıy'ın Kamyonculara Seslenişi & $1: 56$ & 101.825 & 2014 \\
Aleksey Navalnıy'ın Hitabı & $10: 03$ & 770.660 & 2013 \\
\hline Nalavnıy'ın 6 Eylül Konuşması (Saharov Caddesi)
\end{tabular}

Kaynak: https://www.youtube.com/user/NavalnyRu, 2018

Örneklemin temelini "O Dimon Değil"' isimli 49 dakika 38 saniyelik belgesel film niteliğindeki konuşma oluşturmaktadır. Bu konuşma Aleksey Navalnıy'ın kullandığı retoriği tüm ana hatlarıyla ortaya koymaktadır. Bununla birlikte "Vladimir Putin Damadına 1,75 Milyar doları Nasıl Aktardı?", "Platon” sistemi ile ilgili yaptığı “Aleksey Navalnıy'ın Kamyonculara Seslenişi”, ev hapsinden yaptığı "Aleksey Navalnıy'ın Hitabı" ve Moskova belediye başkanlığ 1 adaylığı sırasında yaptığı miting konuşması olan "Nalavnıy'ın 6 Eylül Konuşması (Saharov Caddesi)" başlıklı konuşmalar da aynı şekilde analiz edilmiştir.

\subsection{Aleksey Navalnıy}

Anatoleviç Aleksey Navalnıy 1976 yılında Moskova Oblastı'na bağlı Butın isimli köyde asker bir ailenin çocuğu olarak dünyaya gelmiştir. Hukuk ve ekonomi eğitimi almıştır. 2004 yılında kurduğu "Moskovalıları Koruma Komitesi” yüzü aşkın grubun birleşmesini sağlayarak komşu ev sakinlerine zarar veren bir dizi inşaat projesinin sonlandırmasını sağlamıştır. 2008 yılında Rus devletine ait büyük fonlarda zimmete para geçirme iddiası ile ilgili yayınladığ belgelerin ardından Rusya çapında tanınırlık kazanmaya başlamıștır. Avukat kimliğiyle Azınlık Hissedarları Birliği'ni kurarak Gazprom, Rosneft, Transneft ve Gazpromneft gibi dev enerji şirketlerinin küçük hissedarlara şeffaflık sağlamaları amacıyla bu şirketler aleyhine yasal işlemler

\footnotetext{
${ }^{6}$ Belgeselin “Он вам не Димон” (O Dimon Değil) ismi ile yayınlanması şununla ilgilidir; Başbakan Medvedev'in basın sözcüsü olan Natalya Timakova (Ната́лья Алекса́ндровна Тимако́ва) "Rusya’nın Sesi” isimli radyoya verdiği röportajda Medvedev ile ilgili özellikle sosyal medya üzerinden yapılan bazı yorumların kendisini üzdüğünü belirterek bazılarının ona "Dimon" (Tam adının kullanılması yerine Dmitri isminin "acınası, küçük” bir çocuğa hitap eder gibi lakaplaştırılarak kullanılmasını ifade etmektedir) diye hitap ettiklerini söylemekte ve “O Dimon Değil, Hükümet başkanı” diyerek Medvedev’e saygılı bir şekilde hitap edilmesi gerektiğini söylemektedir (SVOBODA, 2019). Navalnıy buna gönderme yaparak belgeseli “O Dimon Değil” ismi ile yayınlamıștır. Çünkü ona göre Medvedev kesinlikle gerçekten acınası biri değil kurduğu "kukla vakıflar" vasıtasıyla, yolsuzluk ve rüşvetle ülke çapında ciddi gayrimenkul sahibi, seçkin semtlerde dev arazileri olan, lüks köșkleri, yatları daireleri vb. olan biridir (DIMMON NAVALNY, 2019).
} 
başlatmıştır. Adı yolsuzluklara karşı mücadele eden biri olarak anılmaya başlayan Navalnıy 2010 yılında kamu ihalelerinde dolandırıcılık ve haksız rekabetin tespit edilmesi amaciyla RosPil projesini kurmuştur. RosPil projesi Rusya'da kurumsallaşmış aktivizmin önemli unsurlarından kabul edilmektedir (Sidorenko, 2011, s. 8). 2011 yılında Aleksey Navalnıy ülkedeki en büyük bağımsız yolsuzlukla mücadele kuruluşu olan Yolsuzlukla Mücadele Vakfı'nı (kısa adı FBK, Фонд борьбы с коррупцией -ФБК) kurmuştur. (Navalny, 2019a).

Başlangıçta insanları Navalnıy'a çeken şey, yerel düzeyde aşamalı bir ilerleme kaydetme girişimleri olarak nitelendirilebilecek bu ve benzeri taban oluşturma çabaları olmuştur (Jarrell, 2012: 9). Aralık 2012'de seçimlerin adil yapılması için düzenlenen mitingde tutuklanan ve 15 gün boyunca tutuklu kalan Navalnıy hakkında muhalif yazar Viktor Şenderoviç "bir blog yazarı olarak hapse girdi, Rusya'nın gelecek başkanı olarak çıktı" ifadelerini kullanmıştır (Vedomosti, 2012).

2013 yılında Moskova belediye başkanlığ 1 seçimlerinde aday olan Navalnıy resmi rakamlara göre \%27,24 oy alarak ikinci sırada belediye seçimlerini kaybetmiş̧tir. Orttung'a göre Navalnıy, bu seçimlerde Rusya'nın gördüğü en sofistike seçim kampanyasını gerçekleştirmiştir (Orttung and Waller, 2013, s. 1). Aynı dönemde bazı kesimler tarafından halk düşmanı ilan edilen Navalnıy hakkında çeşitli davalar açılmıştır. Bu davalarının en önemlilerinden biri zimmetine para geçirmekle suçlandığı Kirovles davası olarak bilinen davadır. Rus devletine ait Kirovles isimli şirkette danı̧̧manlık yapan Navalnıy bu davadan önce hapis cezası almış, daha sonra Avrupa İnsan Hakları Mahkemesi'nin Navalnıy'ın adil yargılanmadığına hükmetmesi sonucu Rus mahkemeleri Navalnıy'ın yeniden yargılanmasına karar vermiştir. Navalnıy'a göre açılan dava hukuksuz olup Devlet Başkanı Vladimir Putin'in emriyle açılmış bir davadır (Navalny, 2019b). 2015 yılında "İlerleme Partisi" (Partyprogress, 2019) isimli bir parti kurmaya çalışmış ancak partinin resmi olarak kurulmasına izin verilmemiştir (RBC, 2015).

2016 yılında aralarında Başbakan Dmitri Medvedev ve Birincil Başbakan Yardımcısı İgor Şuvalov gibi üst düzey Rus yetkililerin rüşvet ve yolsuzluğa karıştıkları iddia edilen bir dizi belgesel film yayınlamıştır. 2017 yılında 2018'de yapılacak olan başkanlık seçimlerinde aday olacağını açıklayan Navalnıy, başkanlığa aday olmasının desteklenmesi için üç yüz seksen binden fazla imza ve yaklaşık 39 milyon ruble bağış toplamıştır. Aralık 2017'de seçim programını yayınlayan Navalnıy programının ana konularını yolsuzlukla etkin mücadele, eşitsizliklerin ortadan kaldırılması, asgari ücretin artırılması, konut edinme yardımı, devlet tarafindan yapılan sağlı harcamalarının artırılması, küçük girişimcilerin işlerinin kolaylaştırılması ve vergilerin azaltılması, fiyat serbestesi sağlanması, bürokrasinin azaltılması, finans ve yetkilerin Rusya'nın tüm bölgelerinin lehine olacak şekilde yeniden dağıtılması olarak açıklamıştır. Adaylık başvurusunda bulunan Navaynıy'a yetkili makamlar 25 Aralık 2017 tarihinde Kirovles davasında aldığı mahkûmiyet kararı nedeniyle başkanlık seçimlerine aday olamayacağını duyurmuşlardır. Navalnıy bu kararın hukuki değil siyasi bir karar olduğunu ve anayasaya aykırı olduğunu iddia etmiştir. Mahkemeye temyiz için başvuran Navalnıy'ın talebi reddedilmiş ve Navalnıy 18 Mart 2018 yapılacak olan seçimlerin ülke çapında boykot edilmesini ve seçimlere katılım sağlanmamasını istemiştir (Navalny, 2018a).

Putin Navalnıy’ın seçimlere katılmasına müsaade edilmeyen tek kişi olmadığını ama nedense diğerlerinin isminin hiç anılmadığını belirtmiştir. Bunun ise ABD yönetiminin ve diğer Avrupa ülke yöneticilerinin tercihlerini belli ettiğini, Rusya'nın siyaset alanına kimi taşımak istediklerini ve ülkenin lideri olarak kimi görmek istediklerini ortaya koyduğunu söylemiştir (Kommersant, 2018b). Böylelikle Putin soğuk savaş döneminden beri Rus halkının zihninde yer etmiş derin duygulara hitap ederek halkına Navalnıy'ın bir batı ve/veya Amerika projesi olduğu mesajını vermiştir.

Navalnıy uzun süre siyasi faaliyet yürüttüğü sol-liberal Yabloko Partisi'nden (Партия Яблоко) 2007 yılında ırkçı faaliyetler yürüttüğü gerekçesiyle atılmıştır (VZ, 2016). Bu nedenle Navalnıy hakkında dile getirilen en çarpıcı iddialardan biri onun ırkçı veya faşist olduğudur. Onunla birlikte hareket edenlerin sadece göz rengi veya ten rengi farklı olduğu için insanları 
öldürmek için hazır oldukları, Navalnıy'ın etnik temizlik yapmak istediği iddia edilmektedir (KP, 2017). Halihazırda 1rkçılık meselesi Navalnıy’ın üzerini kapattığı, konuşmak istemediği bir konu gibi görünmektedir. Navalnıy günümüzde bu konulara mümkün olduğunca değinmemeye çalışarak politik stratejisini yolsuzlukla mücadele zemininde yürütmeye çalışmaktadır. Ancak kendisinin de yolsuzluk nedeniyle Rus mahkemelerince suçlu bulunmuş olması elini zayıflatmaktadır.

\subsection{Bulgular}

Örneklem için seçilen beş konuşmada en fazla kullanılan mantıksal yanılgılar sırasıyla hatalı kategorilendirme, saldıı, duygulara başvurma, hatalı kıyaslama, şaşırtma, istatistiksel hata, tartışmalı sebep, otoriteye başvurma, belirsizlik ve konunun özünden uzaklaştırmadır.

Tablo 2. Mantıksal yanılgı kullanım sayısı

\begin{tabular}{lc}
\hline Tür & Kullanım Sayısı \\
\hline Hatalı Kategorilendirme & 10 \\
Saldırı & 8 \\
Duygulara Başvurma & 7 \\
Hatalı Kıyaslama & 4 \\
Saşırtma & 3 \\
İstatistiksel Hata & 3 \\
Tartışmalı Sebep & 2 \\
Otoriteye Başvurma & 2 \\
Belirsizlik & 1 \\
Konunun Özünden Uzaklaştırma & 1 \\
\hline
\end{tabular}

Beş konuşmanın toplamında en fazla kullanılan temel retorik unsurlar sırasıyla ironi, metafor, alegori, ritim, karşılaştırma, operasyonel tanımlama ve metonimidir.

Tablo 3. Temel retorik unsurların kullanım sayısı

\begin{tabular}{lc}
\hline Tür & Kullanım Sayısı \\
\hline İroni & 13 \\
Metafor & 5 \\
Alegori & 3 \\
Ritim & 2 \\
Karşılaştırma & 1 \\
Operasyonel tanımlama & 1 \\
Metonimi & 1 \\
\hline
\end{tabular}

“O Dimon Değil” başlıklı konuşmada dinleyici özelde Medvedev'in genelde ise tüm iktidarın yolsuzluk yaptığına ikna edilmeye çalışılmaktadır. Konuşma harekete geçirme amacı taşımakta bu amaca bilgi sağlama, duygulandırma ve eğlendirme yoluyla ulaşmayı arzu etmektedir. Retorik türü olarak suçlama ve müzakereci retorik kullanılmaktadır. Konuşmanın giriş gelişme ve sonuç kısmı iyi bir retoriğe uygun şekilde kurgulanmıştır. Giriş kısmı dinleyicilerin zihinlerini ve dinleyiciyi konuya hazırlayacak, konunun kendisi ile yakından ilgili olduğuna inandıracak şekilde oluşturulmuştur. Gelişme bölümde gerekli kanıtlar uyum içerisinde sunulmuştur. Sonuç bölümde nihai vurgular yapılmıştır. Konuşmada $12 \mathrm{kez}$ ironi, 3 kez alegori kullanılmaktadır. Toplam 3 kez adam karalama, 5 metafor, 1 anlam belirsizliği, 1 karşılaştırma, 1 özelleştirme, 2 bütünleme, 1 ihmal edilebilir neden, 1 indirgeme ve 2 duygu sömürüsü bulunmaktadır. Konuşmanın görüntü unsuru ilgi çekici bir şekilde kurgulanmıştır.

Navalnıy resmi sayılamayacak, samimi, özgüvenli olduğunu göstermeye çalışan diğer taraftan "ben de sizden biriyim" mesajı veren bir üslup kullanmaktadır. Konuşurken iddialarıyla ilgili çok sayıda delil sunarak iyi bir retoriğin ruhuna uygun davranmaktadır. Siyasi rakiplerinin 
çoğunun aksine etkileşimli bir tarz ve üslup kullanması, kullandığı retoriği interaktif ortamların gereksinimlerine göre kurgulaması ise onu farklı kılmaktadır.

Konuşmacının Medvedev ile ilgili "telefonları ve benzeri diğer elektronik aygıtları seven, komik bir budala, önemli etkinliklerde uyuyakalan” biri ifadelerini kullandığı konuşmanın giriş kısmında Medvedev ile ilgili henüz onun dolandırıcı ve rüşvetçi olduğu gibi sert iddiaları dile getirmeden önce Medvedev'in bu iddialar olmasa bile "değersiz" biri olduğunu ima etmektedir.

"Yolsuzluk sadece yasadışı olmamalı, ahlaka aykırı olmalı" gibi Medvedev'in konuşmalarından alıntılanan bölümler onun söylemleri ve faaliyetleri arasında ciddi bir tenakuz olduğunu göstermek / iddia etmek için alıntılanmıştır. Buna göre Medvedev kendisi yolsuzluk yaptığı halde bu konuda rahatlıkla ahkam kesebilen biridir. "Yolsuzluk yapanların boyunlarındaki urgan sürekli ve acımasız bir şekilde sıkılmalıdır ve istisnasız tüm Rus toplumu bu konuda hemfikir" gibi alıntılarla Medvedev’i kendi sözleriyle sıkıştırmaktadır.

Diğer taraftan bu ifade Rusya'daki genel bir algıyı da ortaya koymaktadır. Buna göre Rusya'da yolsuzluk yasalarca suç olmasına karşın birçokları tarafından gayrı ahlaki görülmemektedir. Nitekim Medvedev ilgili konuşmasının tamamında yolsuzluğun Rusya içi çok ağır karmaşık ve önemli bir konu olduğunu belirtmekte ve yapılan bazı araştırmalara göre Rus toplumunun dörtte birinin yolsuzluğu tamamen normal bir durum olarak gördüklerini ifade etmektedir. Buna göre toplumun büyük bir bölümü yolsuzluğu hoş karşılamaktadır. Diğer yandan toplumun neredeyse tamamında yolsuzluğa karşı bir tepkinin olmadığını söylemektedir. Ciddi yolsuzluk iddialarıyla suçlanan bir başbakanın toplumun yolsuzluğu gayrı ahlaki görmediğini söylemesi paradoksal bir durum oluşturmaktadır. Öte yandan Navalnıy açısından yolsuzluğun normal sayıldığı bir toplumda yolsuzluk üzerinden siyasi retorik oluşturmak da paradoksal görünmektedir. Bu tür bir toplumda yolsuzluk temasını siyasal söylemin merkezine yerleştirmek tek başına yeterli olamayabilir. Öncelikle yolsuzluğun "gayrı ahlaki" olarak algılanmasını sağlayacak faaliyetler yürütme ihtiyacı olabilir.

Konuşmada Medvedev'e rüşvet verdiği iddia edilen oligark Alişer Usmanov hakkında "Sovyet madencilik endüstrisinin kalıntılarından büyük bir servet sahibi olan Alişer Usmanov" ifadeleri yer almaktadır. Rusya'da gerek sosyo-politik geçmiş gerekse yoksul nüfus nedeniyle oligarşiye karşı kini olan bir kitle bulunmaktadır. Bu nedenle Navalnıy sadece "Alişer Usmanov" veya "Oligark Alişer Usmanov" dememekte oligarşiyi Usmanov özelinde betimleyerek "Sovyet madencilik endüstrisinin kalıntılarından büyük bir servet sahibi olan" ifadelerini vurgulayarak halka ait olan bir servete haksız yere sahip olduğunu vurgulamaya çalışmaktadır. Putin iktidarının ilk yıllarında oligarklara karşı sert bir tutum sergilemiş Alişer Usmanov da dahil Mihail Prohorov, Roman Abramoviç gibi birçok oligark Rusya'yı terk etmişlerdir. Oligark Mikhail Borisoviç Khodorkovsky'in ülkede kalarak muhalif partileri desteklemesi üzerine hakkında vergi kaçakçılığı suçlamasıyla hapis cezasına çarptırılmıştır. Uluslararası Af Örgütü Khodorkovsky’i siyasi mahkûm/ düşünce suçlusu olarak tanımıştır (Amnesty, 2011). 10 y1l hapis yattıktan sonra annesinin hastalığı nedeniyle affedilmeyi dilediğini söyleyen eski oligark Kremlin tarafından affedilmiş, Almanya'ya taşınmış ve politikadan uzak duracağını açıklamıştır (Telegraph, 2013). Böylelikle çoklarına göre Putin oligarkların kendisine biat etmelerini sağlamış ve etmeyenleri cezalandırmıştır. Dolayısıyla kendi komutası altındaki bir oligarşi sınıfı oluşturduğu iddia edilmektedir. Navalnıy burada bu yeni oligarşinin mevcut durumuna değinmektedir.

Retorikçilere göre güzel bir hitabetin olabilmesi için Ethos'un yani erdemin ve ahlakın olması gerekir. Quintilianus'a göre, "retorik iyi söyleme sanatıdır, çünkü hem söylemin tüm yetkinliklerini hem de hatibin ahlakını kucaklar, çünkü iyi insan olmadan gerçekten iyi konuşmak mümkün değildir (Meyer, 2009, s. 11-35).” Konuşmada Navalnıy'ın Mevedev'in teyzesi Svetlana Afanasyevna Medvedeva'dan bahsederken "Rusya'nın şerefli bir öğretmeni” ifadesini kullanması kendisinin erdemli bir kişi olduğunu gösterme çabası olarak tanımlanabilir. Çünkü konuşmada Afanasyevna'dan bahsedilme sebebi Andrey Vasilyeviç Medvedev ile Dmitri Medvedev arasındaki akrabalık ilişkisini ortaya koymak içindir. Yani Afanasyevna'nın bu konuşmada bahsi 
geçen yolsuzluk, rüşvet vb. şeylerle ilgisi bulunmamaktadır. Bu durumda konuşmacı onun ismini sade bir şekilde vermemiştir. Bunun yerine onun "Rusya'nın şerefli bir öğretmeni” olduğunu özellikle vurgulamıştır. Navalnıy zaten konuşmada hakkında hiçbir itham bulunmayan Afanasyevna'nın "Rusya'nın şerefli bir öğretmeni” olduğunu belirterek onu bu konuşmada adı geçen diğer şahıslardan tenzih etmiştir. Konuşmacı böylelikle erdem sahibi, herkese hakkını veren bir bakıma "düşmanının suçsuz yakınlarına bile sahip çıkan" biri olarak kendini sunmaktadır.

Rus siyasi arenasında boy gösteren, başkanlık seçimlerine katılan diğer siyasi aktörler ile Navalnıy'ın retoriğinin seçmen davranışlarına etkisini incelemek, Navalnıy'ın adaylığının kabul edilmemesi nedeniyle mümkün olmamaktadır. Diğer taraftan seçim güvenliği ile ilgili iddialar ve tartışmalarda seçim sonuçlarından hareketle siyasi figürlerin retoriklerinin etkisinin analiz edilmesine engel olmaktadır. Ancak yine de genel bir kıyaslama yapmak mümkündür.

Tablo 4. 18 Mart 2018 Rusya Federasyonu devlet başkanlığı seçim sonuçları

\begin{tabular}{lrr}
\hline Seçime Katılan Adayların İsimleri & Alınan Oy Sayısı & Yüzdelik Oy Oranları \\
\hline Putin Vladimir Vladimiroviç & 56,430712 & 76,69 \\
Grudinin Pavel Nikolayeviç & 8,659206 & 11,77 \\
Jirinovski Vladimir Volfoviç & 4,154985 & 5,65 \\
Sobçak Kseniya Anatolyevna & 1,238031 & 1,68 \\
Yavlinski Grigori Alekseyeviç & 769644 & 1,05 \\
Titov Boris Yuryeviç & 556801 & 0,76 \\
Suraykin Maksim Aleksandroviç & 499342 & 0,68 \\
Baburin Sergey Nikolayeviç & 479013 & 0,65 \\
\hline
\end{tabular}

Kaynak: (CIKRF, 2018)

Navalnıy kendine rakip olarak Putin'i görmektedir. Neredeyse tüm retoriğini Putin ve Birleşik Rusya partisine muhalefet çizgisinde kurgulumaktadır. Ancak Rus siyasetinde boy gösteren diğer siyasi aktörler başlıca Grudinin, Jirinovski, Sobçak, Yavlinski, Titov, Suraykin ve Baburin olarak siralanabilir.

Resmî sonuçlara göre 18 Mart 2018'de yapılan seçimlere toplam 109,008428 seçmenden 73,578992'si katılmıştır. Buna göre seçimlere katılım oranı \%67,5 olarak tespit edilmiştir. 56,430712 oyla tüm oyların \% 76,69'luk bölümünü alan Putin Vladimir Vladimiroviç seçimlerden galip çıkmıştır.

Putin'in retoriği: Dış basın Putin'in retoriğinin genel itibariyle özellikle son dönemlerde soğuk savaş dönemi retoriğini anımsattığını söylemektedir (Independent, 2018). Diğer taraftan Putin'in iç siyasete yönelik retoriğini incelemek için Rusya'nın demografik özelliklerine bakmak gerekmektedir.

Nitekim2017 Rosstat (Rusya Federal Devlet İstatistikleri Servisi) verilerine göre (GKS, 2019) 2017 yılı itibariyle Rusya'da 82,322000 kişi 35 yaş ve üzeridir. Toplam seçmen sayısının 109,008428 olduğu düşünülürse (CIKRF, 2018) 35 yaş ve üzeri seçmenlerin toplam seçmen sayısına oranı \%75,51'dir. 35 yaşın bir etken olarak alınmış olmasının nedeni bu yaş grubunun Mihail Gorbaçov, Yeltsin, Putin ve Medvedev dönemlerini görmüş olmalarıdır. Sovyetlerin çöküşünü görmüş ve bu dönemde yaşanan sıkıntılara şahitlik etmiş, Yeltsin döneminde maaşların ödenmediği, uzun gıda kuyruklarının oluştuğu, özelleştirmelerle halkın giderek fakirleşirken oligarkların giderek zenginleştiği bir dönemi yaşamışlardır. 1998 yılında yaşanan krizde Rus rublesi Amerikan doları karşısında dört kat değer kaybetmiştir. 31 Aralık 1999 yılında Yeltsin yılbaşı kutlaması yapmadan hemen önce istifa ettiğini açıklamış ve yönetimi o dönemde FSB başkanı olan Putin'e devretmiştir. Böylelikle 2000 yılının başından itibaren 
günümüze kadar Rusya Federasyonu'nu pratikte Putin yönetmektedir. ${ }^{7}$ Sovyetlerin çöküşünde yaşanan travmatik sıkıntıları görmüş, 1998 krizini yaşamış, önemli etkinliklerde Yeltsin'in sarhoş olduğuna müşahede etmiş 35 yaş ve üzeri seçmen için "ciddi devlet adamı" imajını koruyan Putin bir "kurtuluş" olarak görülmüştür. Yeltsin iktidarının hemen akabinde Putin döneminde Rus ekonomisi stabilize olmaya başlamıştır. 1991 ve 2000'li yıllar arasında 10 ila 25 Amerikan doları civarında seyreden petrol fiyatlarının 2000 ve $2008^{\prime}$ li yıllarda 25 ila 100 Amerikan doları civarında seyretmesinin de Putin'in elini oldukça güçlendirdiğini söylemek mümkündür.

Böylelikle Navalnıy'ın hitap ettiği kitle genel itibariyle gençlerden oluşmakta iken Putin'in hitap ettiği genel kitle orta yaşlı ve yaşlı denebilecek bir kitledir. Bu farklılık siyasi retoriğe de yansımaktadır.

Grudinin Pavel Nikolayeviç Retoriği: 8,659206 oyla tüm oyların 11,77’lik bölümünü alan Grudinin Pavel Nikolayeviç seçimlerde en çok oy alan ikinci lider olmuştur. Rusya Federasyonu Komünist Partisi'nin (KPRF) Devlet Başkanı Adayı olan Grudinin'in retoriği klasik sosyalistkomünist diyalektiği çerçevesinde kurgulanan bir retorik yapısına sahiptir. Genel hatlarıyla eğitim, sağlık, barınma vb. ihtiyaçların ücretsiz karşılanacağını, bunun önceden olduğu gibi yine mümkün olduğunu iddia eden bir içeriğe sahiptir. Navalnıy'ın retoriği oldukça yenilikçi, Grudinin'in retoriği ise oldukça gelenekçi ve klasik olarak değerlendirilebilir (Grudininkprf, 2018).

Jirinovski Vladimir Volfoviç Retoriği: 4,154 985 oyla tüm oyların 5,65'lik bölümünü alan Rusya Liberal Demokrat Partisi Başkanı Vladimir Jirinovski Rus siyasi arenasında 1980'li yıllardan beri aktif rol oynamaktadır. Moskova Devlet Üniversitesi Doğu Dilleri Enstitüsü mezunudur. Türkiye ve Türk dili uzmanıdır. Aynı üniversitenin hukuk fakültesini de bitirmiştir (LDPR, 2019). Shekhovtsov'a göre Jirinovski popülist bir retoriğe sahiptir ve bu retoriğin özeti Anti-Amerikancılık, nefret söylemi, ırkçılık ve nasyonalizme dayalıdır. Partisinin isminin "Rusya Liberal Demokrat Partisi" olması ise yanıltıcıdır ve 1990'lı yıllarda SSCB yetkililerinin yeni yeni ortaya çıkmakta olan liberal-demokratik hareketlerini gözden düşürmek ve kafalarını karıştırmak için kurdurmuş olduğu bir partidir (Shekhovtsov and Umland, 2014, s. 14-16). Josh Kovensky göre ise Jirinovski'nin retoriği SSCB'ye ait toprakların yeniden alınması ve Baltık Devletlerini işgalle tehdit etmek gibi bir düzleme odaklanmaktadır ve Rus dış politikası aslında Jirinovski'nin retoriğinin agresif özelliklerini taşımaktadır (Uchıcagogate, 2013). Böylelikle Jirinovski'nin retoriğinin genel hatlarıyla, agresif, Rus ırkçıllğına dayalı bir yapısı olduğu söylenebilir.

Sobçak Kseniya Anatolyevna Retoriği: Navalnıy Retoriği ile kıyas açısından son olarak değerlendirilecek olan Rus siyasi figürü Sobçak Kseniya Anatolyevna'dır. 1,238031 oyla \%1,68 oranında bir oy almasına rağmen Sobçak, Navalnıy açısından dikkate alınması gereken biridir. Bir televizyon sunucusu olan Sobçak 1998 yılında St. Petersburg Devlet Üniversitesi Uluslararası İlişkiler Fakültesi'ne girmiş, 2001 yılında Moskova'ya taşınarak Moskova Devlet Uluslararası İlişkiler Enstitüsü, Uluslararası İlişkiler Fakültesi'ne geçmiştir. Müteakiben Moskova Devlet Diplomasi Enstitüsü Siyasal Bilimler Fakültesi’nde yüksek lisans yapmıştır. 1998 yılında St. Petersburg Devlet Üniversitesi Uluslararası İlişkiler Fakültesi'ne (St. Petersburg Devlet Üniversitesi) girmiştir. Çeşitli televizyon kanallarında yayınlan "Ev-2", "Kim milyoner olmak istemez", "Son Kahraman-6"ve "Çikolata kaplı Sarışın" gibi "reality show" türündeki çeşitli programlara sunuculuk yapmıştır (RİA, 2017).

İlerleyen dönemde muhalif gazeteci kimliği ile ortaya çıkmaya başlamıştır. 2015 yılında Sobçak Navalnıy hakkında "Son yıllarda ülkenin en başarılı siyasi projesi" demiş ve eğer

\footnotetext{
${ }^{7}$ Her ne kadar 2008 yılında Medvedev Devlet Başkanı olarak seçilmişse de Putin'in iki kez üst üste Devlet başkanlığı yaptıktan sonra anayasal olarak en fazla iki kez üst üste devlet başkanı olunabildiği için Medvedev Devlet Başkanı olmuş, Putin başbakan olarak görev yapmıştır. Ancak hemen hemen tüm çevrelerce Medvedev'in başkanlığı döneminde dahi gerçek iktidarın Putin'in elinde olduğu söylenmektedir.
} 
Navalnıy'ın seçimlere katılmasına izin verilirse onun ekibine dahil olmaya hazır olduğunu söylemiştir (SVOBODA, 2017b).

Sonraki süreçte Navalnıy'ın seçimlere katılmasına izin verilmeyişle birlikte Navalnıy seçimleri boykot çağrısı yapmıştır. Bu esnada Sobçak Devlet başkanı adayı olarak seçimlere katılmıştır. Seçim günü Navalnıy ve Sobçak "Navalnıy LIVE" isimli canlı yayın yapan youtube kanalında ciddi bir tartışmaya girişmişlerdir. Sobçak Navalnıy'a kendi yürüttüğü kampanyanın onun pek hoşuna gitmediğini bildiğini ancak bundan sonrası için kendisinin Navalnıy'ın ve aynı değerleri taşıyan diğer muhaliflerin birleşmesi gerektiğini söylemiştir. Yine Sobçak Navalnıy’a kendisinin seçimlere kabul edilmesinin büyük bir haksızlık olduğunu ve Navalnıy'ın ne hissettiğini anladığını söylemiştir. Navalnıy ise bunun kendisinin seçimlere kabul edilip edilmemesiyle ilgili olmadığını, büyük bir entrika düzenlendiğini ve Sobçak'ın da bu "entrikanın" bir parçası olduğunu söylemiştir. Sobçak'ın aday olmasının yegâne amacının seçimleri boykot çağnısını delmek olduğunu söylemiştir. Navalnıy Sobçak'a "Putin'in verdiği görevi yerine getirdin" demiştir. "Kalpazanlara" yardımcı olmakla suçlamıştır. Navalnıy Sobçak'ın birleşme çağrısını "tam bir ikiyüzlülük" olarak adlandırmış bu seçimlerde Sobçak'ın "ikiyüzlülük şampiyonu” olduğunu söylemiştir. Navalnıy bu yayında Sobçak'ın seçimlerden önce kendisine gelerek "bana aday olmam için oldukça yüksek miktarda para teklif ediyorlar" dediğini iddia etmiş Sobçak ise bunu yalanlamıştır. Sobçak'ın aday olarak yolsuzlukların ve hırsızlıkların tartışılmasının yerine, özel hayatının geçmişte sunduğu "reality show" ların tartışılmasına neden olduğunu söylemiştir. Sobçak'ın aday olduğu sırada sosyal medya hesapları üzerinden votka ve havyar reklamı yaptığını, dünyanın hiçbir yerinde bir devlet başkanı adayının buna benzer bir şey yaptığını görmenin mümkün olmadığını söylemiştir. "Havyar reklamı yapan muhalif lider"in bir iki yüzlülük olduğunu ve böylelikle başından beri Sobçak'ın muhalefeti zayıflatmak ve gözden düşürmek için kullanılan bir enstrüman olduğunu iddia etmiştir (Navalnıy LIVE, 2018).

Sobçak'ın retorik açısından zayıf bir görünüm sergilediği söylenebilir. Rus Devlet televizyonu Rusya 1 kanalında seçimlerden önce yapılan açı oturum tarzı programda Jirinovski kendine hakaret etmiş, konuşmaya firsat bulamamış ve ağlamaya başlamıştır. Bu olay gündemde ciddi bir yer tutmuştur (LIFE, 2018). Navalnıy Sobçak'ın muhalefeti zayıflatmak ve gözden düşürmek için kullanılan bir enstrüman olduğunu bu ve benzeri nedenlerden ötürü iddia etmekte ve Sobçak ve diğerlerine kontrollü muhalefet suçlamasında bulunmaktadır.

"Vladimir Putin Damadına 1,75 Milyar doları Nasıl Aktardı?" başlıklı konuşmada dinleyici Putin'in devlet bütçesini yakınlarının çıkarına kullandığına ikna edilmeye çalışılmaktadır. Konuşmada suçlama türünde retorik kullanılmıştır. Konuşma bilgilendirici bir konuşmadır ve konuşmanın harekete geçirici unsuru zayıf da olsa mevcuttur. Konuşmanın giriş gelişme ve sonuç kısmı makul bir şekilde oluşturulmuştur. Konuşmada 1 ironi, 1 operasyonel tanımlama, 1 indirgemeden yararlanılmış olup 1 yerde ritim kullanılmıştır. Görüntü unsuru konuşmanın konusu ile ilgili olacak bir şekilde düzenlenmiştir.

Konuşmada Şamalov ile ilgili yer alan iddialar ABD Hazine Bakanlığı internet sitesinde de yer almaktadır (Treasury, 2018). Konuşmada ortaya atılan iddialar ve talep edilen "çıkar çatışması" bildiriminden sonra yine Quintilianus'un retorikte ahlak görüşlerine uygun bir şekilde Putin'e haksızlık edilmediği, ondan kanuni bir talepte bulunulduğunun söylenmesi önemlidir:

Emimin ki bu durumda kimse Vladimir Putin'in hatasını aradığımızı veya ona haksızlık ettiğimizi söylemez çünkü biz ondan kanunen talep edilemeyecek bir şey istemiyoruz ve onu seviyor olmanız, ondan korkuyor olmanız, ona hayran olmanız, ondan nefret ediyor olmanız gibi ona karşı olan tutumunuzdan bağımsız olarak muhtemelen siz de doğru olanın ülkenin cumhurbaşkanının lüzumu durumunda çıkar çatışması bildirmesi gerektiğini düşünüyorsunuzdur.

“Aleksey Navalnıy'ın Kamyonculara Seslenişi” başlıklı konuşmada dinleyici dinleyici "Platon" sistemine karşı yapılacak olan protesto eylemlerine katılmaya ikna edilmeye çalışılmaktadır. Konuşmada müzakereci ve hukuki retorik suçlama ile birlikte kullanılmıştır. 
Konuşmanın bilgilendirici ve harekete geçirici unsurları bulunmaktadır. Giriş gelişme ve sonuç kısmı doğal akış şeklinde kurgulanmış olup retorik yöntemlere uygun görünmektedir. Konuşmada 2 dolduruşa getirme, 1 adam karalama, 1 niteliksel adam karalama, 1 duygu sömürüsü 4 bütünleme yanılgıs1, 1 yanlış benzetme kullanılmıştır.

Konuşmada kamyonculara protesto eylemlerine katılmamaları için birçok çağrıda bulunulduğu belirtilmektedir. Örneğin Milletvekili Yevgeny Alekseyeviç Födorov bu eylemin Navalnıy'ın bir kalkışma için militan hazırlama eylemi olduğunu, dış güçler tarafından provoke edildiğini söylemiştir (Gazeta, 2015).

“Aleksey Navalnıy'ın Hitabı” başlıklı konuşma hedef kitlesini Birleşmiş Milletler Yolsuzlukla Mücadele Sözleşmesi'nin yirminci maddesini onaylamasını ve ceza kanununa yasadışı zenginleşme ile ilgili özel bir maddenin konulmasını hususunda kanun taslağının desteklenmesi için imza vermeye ikna etmeye çalışmaktadır. Konuşmada müzakereci retorik ve suçlama birlikte kullanılmıştır. Bilgilendirme ve harekete geçirme hedeflenmiştir. Giriş gelişme ve sonuç bölümü diğer konuşmalara nazaran daha zayıf kurgulanmıştır. Konuşmada 2 genelleştirme, 1 bütünleme, 1 siyah-beyaz yanılgısı ve 1 felaket tellallığı kullanılmıştır.

“Nalavnıy'ın 6 Eylül Konuşması (Saharov Caddesi)” başlıklı konuşma seçimlerde oy kullanmaya gitmeyen kitleyi sandığa götürmeye ikna etmeye çalışmaktadır. Retorik türü olarak suçlama, müzakereci retorik ve övgü kullanılmaktadır. Giriş, gelişme ve sonuç kısmı duygulandırmaya dayalı bir zemin üzerine kurgulanmıştır. Konuşmada 1 irrasyonel otorite, 1 ortak tutuma başvurma, 3 duygu sömürüsü, 1 genelleştirme, 1 metonimi, 1 yetersiz örnek, 1 dolduruşa getirme, 1 ritim, 1 çok sorulu yanılgı, 1 alakasız sonuç yanılgısı, 1 önyargılı dil, 1 karmaşık sebepler ve 1 yok sayma unsuru kullanılmıştır.

\section{Sonuç}

Günümüzde Rusya'da "çok fazla enformasyon, çok az demokrasi” olarak adlandırılabilecek bir iletişim paradoksu mevcut bulunmaktadır. Son yıllarda Rus medyasının, özellikle televizyonun ekonomik istikrarı Vladimir Putin yönetiminde sürekli bir şekilde artmaktadır. Ancak medya şirketlerinin büyümesine rağmen Rusya'da medya çoğulculuğu ve fikir çeşitliliğinde belirgin bir düşüş görülmektedir. Rus toplumunun tüm kesimleri kitle iletişim araçlarını siyasi iktidarı kontrol edebilen bir güçten ziyade, bizzat birer siyasi aktör olarak algılamaktadır. Bu sebeple, bugün Rusya'da yukarıdan aşağıya açık bir devlet sansürü sistemi görünmese de bir dizi iç içe geçmiş sosyal faktörler kümesi nedeniyle medya demokratik sürece katkıda bulunmakta özgür değildir. Böylelikle medyada "nesnellik" kavramı profesyonel olarak kabul edilmemektedir. Medya toplumun gözünde liderler tarafından "siyasi piyon" olarak kullanılan ve bir bilgi tedarikçisinden ziyade "otoritenin sesi" olarak görülen bir olgu olarak karşımıza çıkmaktadır. Bu durumu sadece Sovyetlerden kalma bir durum olarak veya otoriterliğin bir sonucu olarak görmek yeterli değildir. Rus medya sistemini yönlendiren güçler daha incelikli ve karmaşıktır (White, 2014, s. 130-131).

Geçmişte 1rkçı bir siyasetçi olarak anılmasına rağmen günümüzde "yolsuzlukla mücadele ve demokrasi kahramanına" dönüşen/dönüştürülen Navalnıy'ın, bu değişim ve bununla birlikte gelen başarısının en önemli unsurlarından biri kullandığı retoriktir. Siyasal iletişimde siyasilerin kullandığ 1 retorik ciddi bir önem arz etmektedir. Bu sebeple diğer rakiplerine kıyasla müspet veya menfi farklı bir retoriğe sahip olan siyasiler dünya siyasi arenasında dikkat çekmektedirler. $\mathrm{Bu}$ çalışma kapsamında böyle farklı bir retorik türüne sahip olan Rus siyasi muhalif lider Aleksey Navalnıy'ın 2013-2017 yılları arasında youtube.com üzerinden yayınladığı beş konuşmasının retorik analizi yapılmıştır.

Navalnıy'ın kullandığı retorik köklü Rus siyasetçilerinin kullandığı retorikten içerik ve yöntem olarak oldukça farklıdır. Rakiplerine göre daha dinamik ve interaktif bir retoriğe sahiptir. Dikkat çekmek ve ilgiliyi arttırmak için sıklıkla ironi, metafor ve alegori kullanmaktadır. Ayrıca çokça hatalı kategorilendirmeyle başvurarak dinleyiciyi arzu ettiği çıkarımları yapması için 
yönlendirmekte, saldırı yöntemiyle rakiplerini itibarsızlaştırmakta ve duygulara başvurma yöntemiyle hedef kitleyi konunun tarafı haline getirmeye çalışmaktadır. Kitlesini marjinalleştirdiği ve terörize ettiği gibi iddia ve eleştirilerin temelini gerçekleştirdiği toplumsal gösteriler oluştursa da bunu sağlayabiliyor olmasının nedeni toplumun belirli bölümünün sosyopsikolojik durumlarını tespit edebilmiş ve buna uygun bir retorik ile ortaya çıkmış olmasıdır. Kullandığı retoriğin en büyük argümanı yolsuzluktur. Rusya'nın Uluslararası Yolsuzluk Algılama Endeksi verilerine göre 180 ülke arasında 135. sirada bulunması bu argümanı neden siklıkla kullandığının cevabı olabilecek niteliktedir (Transparency, 2017). Nitekim örneklem kapsamında seçilen beş konuşmanın tamamı yolsuzluk teması üzerine kuruludur.

Navalnıy maruz kaldığı siyasi baskıları ve hukuki yaptırımları da lehine çevirebilmektedir. Bu noktada kullandığı retoriği bir "mağdur edebiyatı" değil bir "mücadele adamı" çizgisinde kurgulamaktadır. Ev hapsindeyken bile yolsuzluk ile ilgli konuşmalar yaparak yayınlamakta, televizyonlarda kendisine yer verilmiyor oluşunu şikâyet ederek değil "Gördüklerinizi akrabalarınıza anlatın. Evet, televizyon tamamen bu mafyanın kontrolü altında ve bu gerçekler hakkında tek bir kelime bile etmeyecekler ancak bizler insandan insana bilgi aktararak sansürün üstesinden gelebiliriz." diyerek mücadeleci bir imaj oluşturmaktadır.

Analizden elde edilen sonuçlara göre Navalnıy'ın kullandığı retoriğin ciddi bir kurgu gerektirdiğini gözlemlemek mümkündür. Böylelikle Navalnıy'ın görece başarısında bu retoriğin büyük etkisinin olduğunu söylenebilir. Ayrıca medya demokratik sürece katkıda bulunmakta özgür olmamasına rağmen, tabandan gelen şeffaf ve demokratik toplum talebinin de bu başarıda rolünün olduğunu söylemek mümkündür. İlerleyen süreçte Rus siyasetinde bu tür bir retoriğin kullanımını irdelemek ve ortaya çıkaracağı toplumsal değişimi gözlemlemek Rusya'nın geleceği konusunda 1ş1k tutabilecek sonuçlar ortaya koyma potansiyeline sahiptir.

\section{Kaynakça}

Adorno, T. W. (2014). Negatif diyalektik (Ş. Öztürk, Çev.). İstanbul: Metis Yayınları.

Alatl1, A. (2001). Safsata kılavuzu laf ola beri gele. İstanbul: Boyut Yayınları.

Aleksey Navalnıy. Lider Partii Rossiya Buduşego, Uçereditel Fonda Borbı s Korruptsiey, Sin, Muj, Otets. https://navalny.com (Erişim tarihi: 10.02.2019b).

Aleksey Navalnıy. On vam ne dimon. https:// dimon.navalny.com (Erişim tarihi: 10.02.2019).

Aleksey Navalnıy. Poçemu Navalnıy nevinoven. https://navalny.ru (Erişim tarihi: 10.02.2019b).

Alekseyev, O. Y. (2008). PR v sisteme politiçeskih kommunikatsiy sovremennoy Rossii, İvestiya Rossiyskogo Gosudarstennogo Pedagogiçeskogo Universiteta im. Aİ Gertsena, 69, $11-17$.

Amnesty International UK (2011). Russia: Khodorkovsky and Lebedev are prisoners of conscience. https://www.amnesty.org.uk (Erişim tarihi: 10.02.2019).

Baudrillard, J. (2012). Kusursuz cinayet. (N. Sevil, Çev.). İstanbul: Ayrıntı Yayınları.

BBC (2018). Russia profile - timeline. http://www.bbc.com (Erişim tarihi: 16.02.2019).

Bennett, B. (2012). Logically fallacious: The ultimate collection of over 300 logical fallacies (Academic Edition). Boston: Ebookit.

Berger, A. A. (2000). Media and communication research methods: an introduction to qualitative and quantitative approaches. London: Sage Publications.

Berger, A. A. (2016). Media and communication research methods: an introduction to qualitative and quantitative approaches. London: Sage Publications. 
Borradori, G. (2008). Terör günlerinde felsefe: jürgen habermas ve jacques derrida ile diyaloglar. (E. Barca, Çev.). İstanbul: Yapı Kredi Yayınları.

Boyer, A. (1996). A linguistic analysis of turkish political language. Ankara: Hacettepe Üniversitesi, Sosyal Bilimler Enstitüsü.

Carson-Newman A Christian University- Dr. L. Kip Wheeler Website. Logical fallacies handlist. https://web.cn.edu/kwheeler/ (Erişim tarihi: 10.02.2019).

Cevizci, A. (1999). Felsefe sözlüğü. İstanbul: Paradigma Yayınları.

Chebankova, E. (2015). Competing ideologies of Russia's civil societ. Europe-Asia Studies, 67(2), 244-268. doi:10.1080/09668136.2014.1002695

Cheskin, A. and Luke, M. (2015). State-society relations in contemporary Russia: New forms of political and social contention. East European Politics, 31(3), 261-267. doi: 10.1080/21599165.2015.1063487

Condor, S., Tileaga, C. and Billig, M. (2013). Political rhetoric. Oxford: Oxford University Press.

Çobanoğlu, Ş. (2007). Suskunluk sarmalı ve siyasal iletişim. İstanbul: Fide Yayınları.

Derrida, J. (1999). Platon'un eczanesi. (Z. Direk, Çev.), Toplumbilim Derrida Özel Sayısı,10, 6381.

Eagleton, T. (2006). Kuramdan sonra. (U. Abac1, Çev.). İstanbul: Literatür Yayınları.

Eagleton, T. (2012). Edebiyat olayı. (B. Yüce, Çev.). İstanbul: Sel Yayıncılık.

Eagleton, T. (2014). Edebiyat kuramı: giriş. (T. Birkan, Çev.). İstanbul: Ayrıntı Yayınları.

Elektronnoye Periodiçeskoye İzdaniye Vedomosti (2012). Çem zarabatıvayet na jizn Aleksey Navalnıy. https://www.vedomosti.ru (Erişim 22.02.2019).

Evans, A. (2011). The failure of democratization in Russia: A comparative perspective. Journal of Eurasian Studies, 2(1), 40-51. doi:10.1016/j.euras.2010.10.001

Evans, A. (2012). Protests and civil society in Russia: The struggle for the khimki forest. Communistand Post-Communist Studies, 45(3-4), 233-242. doi: 10.1016/j.postcomstud.2012.06.002

Federalnaya Slujba Gosudarstvennoy Statistiki. Çislennost naseleniya Rossiyskoy Federatsii po polu $i$ vozrastu. http://www.gks.ru (Erişim 03.01.2019).

Gazeta.RU (2015). Deputat Federov sçitayet protestı dalnoboyşikov podgotovkoy boyevikov Navalnogo k maydanu. https://www.gazeta.ru/ (Erişim tarihi: 27.03.2019).

Gel'man, V. (2013). Cracks in the wall: Challenges to electoral authoritarianism in Russia. Problems of Post-Communism, 60(2), 3-10. doi: 10.2753/PPC1075-8216600201

Jarrell, A. (2012). Local democracy in Russia: An antidote for an aimless protest movement. Russian Analytical Digest, 118(2), 8-10.

Koesel, K. J. and Bunce, V. J. (2012). Putin, popular protests, and political trajectories in Russia: A comparative perspective. Post-Soviet Affairs, 28(4), 403-423. doi: 10.2747/1060586X.28.4.403

Kommersant (2018a). Vlasti Moskvi nazvali nepravomernoy aktsiyu oppozitsii 28 yanvarya. https://www.kommersant.ru (Erişim tarihi: 01.03.2019).

Kommersant (2018b). Putin: SŞA prokololis s kritikoy nedopuska Navalnogo $k$ viborom. https://www.kommersant.ru (Erişim tarihi: 18.02.2019). 
Komsomolskaya Pravda (2017). Dvoynıye standartı youtube. https://www.kp.ru/ (Erişim tarihi: 13.02.2019).

Liberalno-Demokratiçeskaya Partiya Rosii. Lider biografiya. https://ldpr.ru (Erişim tarihi: 20.02.2019).

Lieber, F. (1880). Legal and political hermeneutics: Or principles of interpretation and construction in law and politics, with remarks on precedents and authorities, Boston: St. Louis: F.H. Thomas and Company.

Life News Media (2018). Televeduşaya Zayavila çto lider LDPR Vladimir Jirinovskiy ne dal yey vstavit i slova. https://life.ru (Erişim tarihi: 08.02.2019).

Marozova, G. V. (2010). Politiçeskiye kommunikatsii v Rossii kak elemen publiçnoy politiki. Kazanskiy Universitet, Kazan.

Megill, A. (1998). Aşırıllı̆ıı peygamberleri-nietzsche, heidegger, foucault, derrida. (T. Birkan, Çev.). Ankara: Bilim ve Sanat Yayınları.

Meyer, M. (2009). Retorik. (İ. Yerguz, Çev.). Ankara: Dost Kitabevi Yayınları.

Mulgan, G. (1995). Apolitik çağda politika. (A. Yılmaz, Çev.). İstanbul: Ayrıntı Yayınları.

Musialowska, E. A. (2008). Political Communication in Germany and Poland (PhD thesis). Technical University of Dresden Faculty of Arts, Dresden.

Navalnıy LIVE YouTube (2018). Debatı Navalnogo $i$ Sobçak. polnaya versiya. https://www.youtube.com (Erişim tarihi: 10.02.2019).

Nezavisimoye Analitiçeskoye Obozreniye (2008). Itogi vseh prezidentskih vıborov v Rossii 1991, 1996, 2000 i 2004 godov $i$ glavnaya intriga prezidenstskih viborov 2008. http://www.polit.nnov.ru (Erişim tarihi: 04.02.2019).

Ofitsalnıy İnternet-Portal Pravovoy İnformatsii Gosudarstvennaya Sistema Pravovoy İnformatsi (2014). Rossiyskaya Federatsiya federalnıy konstitutsionniy zakon o prinyatii v rossiyskuyu federatsiyu respubliki Krım i obrazovanii v sostave Rossiyskoy Federatsii novih subyektovrespubliki Krım i goroda federalnogo znaçeniya Sevastopolya. http://pravo.gov.ru (Erişim tarihi: 16.02.2019).

Orttung, R. W. and Waller, J. G. (2013). Navalny and the Moscow mayoral election. Russian Analytical Digest, 136, 2-12. doi:10.3929/ethz-a-009978989

Partiya Progressa, https://partyprogress.org/ (Erişim 03.03.2019).

Pavel Grudinin KPRF, http://grudininkprf.ru (Erişim 03.06.2018).

Radio Svoboda (2017a). Kto ubral Borisa Nemtsova?. https://www.svoboda.org (Erişim 19.02.2019).

Radio Svoboda (2017b). Kseniya Sobçak: Navalnıy- samıy uspeşnıy proyekt poslednih let. https://www.svoboda.org (Erişim 21.02.2019).

RBK (2015). Partiyu Navalnogo lişili registratsii. https://www.rbc.ru (Erişim tarihi: 14.02.2019).

Revolvy. Political rhetoric and campaign 2008. https://www.revolvy.com (Erişim tarihi: 08.11.2017).

RİA Novosti (2017). Biografiya Ksenii Sobçak. https://ria.ru (Erişim 26.02.2019).

Russkiy Dom (2016). Liliputin na fone Gullivera Nemtsova. http://russiahousenews.info (Erişim tarihi: 27.02.2019).

Shekhovtsov, A. and Umland, A. (2011). Vladimir Zhirinovsky and the LDPR. Russian Analytical Digest, 102, 14-16. 
Sidorenko, A. (2011). Russian digital dualism: Changing society, manipulative state. IFRI Russia/NIC Center Working Paper, 63, 4-25.

Solomon, R. C. (2004). Adalet tutkusu: toplum sözleşmesinin kökenleri ve temellerindeki duygular. (E. Altınay, Çev.). İstanbul: Ayrıntı Yayınları.

Stanford Encyclopedia of Philosophy (2015). Fallacies. https://plato.stanford.edu (Erişim tarihi: 06.01.2019).

Sternin, İ. A. (2003). Praktiçeskaya ritorika. Moskva: İzdatelskiy Tsentr Akademiya.

Tepebaş111, F. (2016). Retorik konuşma sanatı- söz bilimi. Konya: Çizgi Kitabevi.

The Independent (2018). Russia rolls back Putin's cold war-era rhetoric as Kremlin denies 'nuking Florida' in video mock-up. http://www.independent.co.uk (Erişim tarihi: 17.01.2019).

The New York Times (2016). Putin 'probably approved' litvinenko poisoning, british inquiry says. http://www.nytimes.com (Erişim tarihi: 28.02.2019).

The Telegraph (2013). Mikhail Khodorkovsky pledges: I'll return to Russia but won't fight Putin. https://www.telegraph.co.uk (Erişim tarihi: 03.01.2019).

The University of Chikago Institute of Politics The Gate (2013). Vladimir Zhirinovsky: A profile. http://uchicagogate.com (Erişim tarihi: 06.03.2019).

Transparency International (2017). Corruption perceptions index 2017. https://www.transparency.org (Erişim tarihi: 09.02.2019).

Tsentralniy Bank Rossiyskoy Federatsii. US dollar/ruble and euro/ruble exchange rates and exchange trade indicators. https://www.cbr.ru (Erişim 16.02.2019).

Tsentralnoy İzbiratelnoy Komissii Rossiyskoy Federatsii. Rezultatı vıborov prezidenta Rossiyskoy Federatsii. http://www.cikrf.ru (Erişim 04.01.2019).

U.S. Department Of The Treasury (2018). Treasury designates Russian oligarchs, officials, and entities in response to worldwide malign activity. https://home.treasury.gov (Erişim tarihi: 22.02.2019).

Van Dijk, T. A. (1997). Discourse as structure and process: discourse studies: a multidisciplinary introduction. London: Sage Publications.

Volkov, D. (2012). The protestors and the public. Journal of Democracy, 23(3), 55-62.

Vzglyad Delovaya Gazeta (2016). Muhin: Navalniy yavlyayetsya kostllem dlya partii Yabloko. https://vz.ru (Erişim tarihi: 24.02.2019).

White, S., Sakwa, R. and Hale, H. E. (2014). Developments in russian politics 8. Basingstoke: Palgrave Macmillan Limited.

Yüksel, A. H., Sandıkçıoğlu, B., Onay, A. ve Yılmaz, A. (1994). İkna edici iletişim. Eskişehir: Anadolu Üniversitesi Yayınları.

ETIKK ve BİLIMSEL İLKELER SORUMLULUK BEYANI

$\mathrm{Bu}$ çalışmanın tüm hazırlanma süreçlerinde etik kurallara ve bilimsel atıf gösterme ilkelerine riayet edildiğini yazar(lar) beyan eder. Aksi bir durumun tespiti halinde Afyon Kocatepe Üniversitesi Sosyal Bilimler Dergisi'nin hiçbir sorumluluğu olmayıp, tüm sorumluluk makale yazarlarına aittir. 